\title{
RT-PCR Method for Detecting Cowpea Mottle Carmovirus in Vigna Germ Plasm
}

\author{
A. G. Gillaspie, Jr., and S. E. Mitchell, USDA, ARS, Plant Genetic Resources Conservation Unit, Griffin, GA \\ 30223-1797; and G. W. Stuart and R. F. Bozarth, Department of Life Sciences, Indiana State University, Terre \\ Haute 47809
}

\begin{abstract}
Gillaspie, A. G., Jr., Mitchell, S. E., Stuart, G. W., and Bozarth, R. F. 1999. RT-PCR method for detecting cowpea mottle carmovirus in Vigna germ plasm. Plant Dis. 83:639-643.

A highly sensitive reverse transcription-polymerase chain reaction (RT-PCR) method was developed to detect cowpea mottle carmovirus (CPMoV) in newly acquired germ plasm of Vigna spp. It detected virus in tissues diluted up to $10^{-9}$. The preferred primers were designed from the RNA replicase cDNA sequence of CPMoV. These primers were able to detect CPMoV in plants infected with 10 different isolates of the virus. There were no cross-reactions with either bean mild mosaic or melon necrotic spot carmoviruses or any of the common cowpea viral pathogens tested. The RT-PCR method was up to $10^{5}$ times more sensitive than direct antigen coating enzyme-linked immunosorbent assay (DAC-ELISA) in detecting CPMoV. The RT-PCR method gave no false positive reaction as is sometimes seen with ELISA.
\end{abstract}

Cowpea mottle carmovirus (CPMoV) was first described from Nigeria (9) as a causal agent of a serious disease of cowpea (Vigna unguiculata (L.) Walp. subsp. unguiculata) and bambarra groundnut ( $V$. subterranea (L.) Verdc.). Cowpea yield reductions of more than $75 \%$ were reported from Nigeria (9). The virus continues to occur throughout Nigeria, where it was found in 8 to $10 \%$ of cowpea samples surveyed (11). It is readily transmitted by sap inoculations and by several chrysomelid beetle vectors $(4,12)$. The virus is transmitted in the seed of cowpeas at a rate up to $10 \%$ depending on the genotype of the line and the time between infection and flowering $(4,10)$, but many lines produced no more than $0.4 \%$ infected seeds (1). Because it is seed transmitted and has potentially serious effects once established in a growing area, CPMoV is of great importance in international exchange of Vigna germ plasm and in germ plasm collections.

Gillaspie et al. (5) described a procedure for detecting and eliminating exotic seedborne viruses from cowpea seed lots. It involves growing seedlings from each seed lot, testing for viruses by enzyme-linked immunosorbent assay (ELISA), and then growing the healthy mother plants to produce virus-free seed that can be increased for storage and distribution. A shortcoming of this method for $\mathrm{CPMoV}$ is that with

Corresponding author: A. G. Gillaspie, Jr.

E-mail: s9gg@ars-grin.gov

Accepted for publication 23 March 1999.

Publication no. D-1999-0426-04R

This article is in the public domain and not copyrightable. It may be freely reprinted with customary crediting of the source. The American Phytopathological Society, 1999. some cowpea genotypes, there are occasional borderline ELISA reactions. The virus could not be isolated from many of these plants by bioassay on cowpea indicator plants.

The genome of CPMoV is a positive sense ssRNA of 4,029 nucleotides with six major open reading frames (ORFs) (14). ORF2 encodes the putative RNA replicase (REP) and ORF5 encodes the capsid protein (CP). To establish a more specific and sensitive test for $\mathrm{CPMoV}$, primers were designed corresponding to both the REP and the $\mathrm{CP}$ coding regions of the nucleic acid and were evaluated for use in a reverse transcription-polymerase chain reaction (RT-PCR) detection method.

\section{MATERIALS AND METHODS}

Virus isolates and propagation. A number of isolates of $\mathrm{CPMoV}$ were used to develop the method and to test the efficacy for different isolates. Virus isolates ISU, AT, Mokwa, Ibadan, Moor Plantation, and Bambarra groundnut came from Nigeria, and isolates 23-48/96, 23-49/96, 23-50/96, and 23-83/96 came from Togo. We had five isolates of Mokwa and six each of Ibadan, Moor Plantation, and Bambarra groundnut. Isolate ISU has been described and sequenced $(6,10,14)$ and is the one from which the primers were designed. Two additional carmoviruses, bean mild mosaic virus (BMMV) and melon necrotic spot virus (MNSV), were supplied by V. Hari and D. M. Rochon, respectively, and were used to evaluate the specificity of the primers.

Crude extracts of $\mathrm{CPMoV}$ isolates were inoculated to cowpea cv. Early Ramshorn grown at $27^{\circ} \mathrm{C}$ for $12 \mathrm{~h}$ light and $23^{\circ} \mathrm{C}$ for $12 \mathrm{~h}$ dark in pots of MetroMix 300. For production of seeds from infected plants, two pots of five seedlings each of PI
582567, 582568, 582575, 582658, 582659, 582660, 582661, 583521, and Early Ramshorn were inoculated with isolate ISU at the primary leaf stage and grown until mature seeds were harvested. California Blackeye no. 5 seedlings were inoculated as long as 4 weeks after the primary leaf stage and became infected. After drying for 7 to 10 days, seeds were sown in flats of 50 each, and the seedlings were grown until the thirdtrifoliolate stage. When testing the crossreactivity/specificity of the primers among CPMoV isolates, cowpea accession PI 471475 was used for propagating the virus. BMMV and MNSV were used as purified virus and were not increased for the crossreactivity tests with other carmoviruses.

Serological testing of plants to verify infection was done by direct antigen coating enzyme-linked immunosorbent assay (DACELISA), as described by Gillaspie et al. (5). G. Thottappilly provided the polyclonal antiserum against CPMoV-AT. DAC-ELISA was used to test tissue extracts with all isolates and to test seedlings in seed transmission studies.

Nucleic acid extraction. Initial experiments were conducted using CPMoV-RNA from purified virus. Isolates ISU and AT were multiplied in cowpea cv. Early Ramshorn for 2 weeks and purified either by differential ultracentrifugation and sucrose density gradient centrifugation as described (4), or by a modified method. The latter involved extraction of the virus in $0.1 \mathrm{M}$ potassium phosphate, $\mathrm{pH} 7.0$, followed by treatment with $2 \%$ Triton $\mathrm{X}-100$ and precipitation of the virus with $10 \%$ polyethylene glycol $(8,000 \mathrm{MW})$ plus $0.1 \mathrm{M} \mathrm{NaCl}$ (13). The virus was further purified on a 10 to $40 \%$ sucrose density gradient at 100,000 $\times g$ ultracentrifugation for $2 \mathrm{~h}$. Virus bands were collected by needle puncture, and the virus was sedimented at $110,000 \times g$ for $2.5 \mathrm{~h}$. Virus pellets were resuspended in $0.1 \mathrm{M}$ phosphate, $\mathrm{pH}$ 7.0. RNA extraction from the purified virus preparations was performed by incubation at $37^{\circ} \mathrm{C}$ with $1 \%$ sodium dodecyl sulfate (SDS) and $1 \mathrm{mM}$ EDTA, followed by phenol:chloroform (1:1) extraction. The RNA was precipitated by addition of 2.5 volumes of cold ethanol and 0.1 volume of $3 \mathrm{M}$ sodium acetate, $\mathrm{pH}$ 5.2 , and incubation at $-20^{\circ} \mathrm{C}$ for $1 \mathrm{~h}$. Nucleic acid was pelleted at $14,000 \times g$ for 10 min in a microfuge. The pellet was washed with $70 \%$ cold ethanol, vacuum dried, and suspended in nuclease-free water. The RNA was extracted from purified BMMV and MNSV virions in the same manner. 
Total RNA was extracted from fresh tissue as described by MacKenzie et al. (7). This method utilized a modified RNeasy Miniprep technique (Qiagen Inc., Chatsworth, CA). RNA was eluted from columns with RNase-free water, and RNA preparations were stored at $-20^{\circ} \mathrm{C}$. All RNAs were quantified based on $A_{260}$ readings.

Primer design. Primers (Table 1) were designed from sequences available in GenBank accession number NID g885949 using a computer program (DesignerPCR 1.03 program, Research Genetics, Huntsville, AL) (14). Two strategies were used for selecting primer sequences. The first strategy utilized three sets of nonredundant primers. One set targets the region between nt 2,674 and nt 3,777, which includes the $3^{\prime}$ end of the CP gene and its flanking 3' untranslated region (UTR) $(\mathrm{CP} 3381 \mathrm{~F}$ and UTR3969R). A second set of primers targets the REP gene between nt 776 and nt 2,263 (REP1667F and REP1990R). The third set targets a region that includes both the replicase gene and the movement protein gene, sharing one primer with the previous set (REP1667F and MOV2666R).

A second approach to primer design was based upon the report of Morozov et al. (8), in which highly conserved areas within the RNA polymerase region were used to design degenerate primers for detection of several carmoviruses. Two degenerate forward primers corresponding to regions II and IV and two degenerate reverse primers corresponding to regions $\mathrm{V}$ and VI of the polymerase region were designed so that there were four possible combinations of these primers. All primers were synthesized by Genosys Biotechnologies, Inc., Woodlands, Texas.

RT-PCR. For first-strand c-DNA synthesis, $25 \mathrm{pM}$ of the reverse primer was added to either $0.3 \mu \mathrm{g}$ of CPMoV RNA extracted from purified virus or $3 \mu \mathrm{g}$ of total RNA from infected leaf tissue in a total volume of $11 \mu \mathrm{l}$. The reaction was incubated at $94^{\circ} \mathrm{C}$ for $2 \mathrm{~min}$ and immediately chilled to $4^{\circ} \mathrm{C}$. After primer annealing, $4 \mu \mathrm{l}$ of $5 \times$ first-strand buffer, $2 \mu \mathrm{l}$ each of $0.1 \mathrm{M}$ DTT and $10 \mathrm{mM}$ dNTPs, $0.25 \mu \mathrm{l}$ of SUPERSCRIPT RT RNase $\mathrm{H}^{-}$Reverse Transcriptase (Gibco BRL), and $0.75 \mu$ l of RNase-free water were added. The reaction $\operatorname{mix}(20 \mu \mathrm{l})$ was then incubated at $37^{\circ} \mathrm{C}$ for $1 \mathrm{~h}$ followed by a treatment at $94^{\circ} \mathrm{C}$ for 2 min to inactivate the enzyme.

Reverse transcription products (1 to 3 $\mu \mathrm{l})$ were used in a PCR reaction consisting of $1 \times$ PCR buffer, 1.5 to $3 \mathrm{mM} \mathrm{MgCl}_{2}, 0.2$ $\mathrm{mM}$ dNTPs, $5 \mathrm{pM}$ each of upstream and downstream primers, and 1 U Taq DNA polymerase (Amplitaq, Perkin Elmer or Promega, Madison, WI). The nondegenerate primer pairs from the REP region gave good amplification at $1.5 \mathrm{mM} \mathrm{MgCl}$. The primers from the $\mathrm{CP}$ region and the degenerate primers did not perform as well as these two pairs, so the specifics of these will not be mentioned. Cycling times and temperatures were as follows: REP1667F/ REP1990R and REP1667F/MOV2666R = one cycle of $94^{\circ} \mathrm{C}$ for $2 \mathrm{~min}, 25$ cycles of $94^{\circ} \mathrm{C}$ for $1 \mathrm{~min}, 52.5^{\circ} \mathrm{C}$ for $2 \mathrm{~min}, 72^{\circ} \mathrm{C}$ for $3 \mathrm{~min}$, one cycle of $72^{\circ} \mathrm{C}$ for $10 \mathrm{~min}$. Products were analyzed by electrophoresis in a $1.5 \%$ agarose gel in $1 \times \mathrm{TBE}$ buffer.

The PCR products from the nondegenerate primer reactions were directly sequenced to determine whether the DNA sequences matched the predicted amplified sequence, and the results were compared with known sequences by BLAST search of GenBank $(2,3)$.

DNA sequencing and data analysis. Amplified fragments were visualized on $1.2 \%$ agarose gels, and DNA concentrations were determined by comparison with a quantitation standard (HindIII fragments of bacteriophage lambda DNA). Singlestranded DNAs and unincorporated dNTPs were degraded by treating the PCR reaction mixtures with a mixture of enzymes. A portion (5 to $10 \mu \mathrm{l})$ of each reaction was incubated at $37^{\circ} \mathrm{C}$ for $15 \mathrm{~min}$ with exonuclease I (10 U) and shrimp alkaline phosphatase (1 U) (Amersham Life Science, Inc., Arlington Heights, IL). The enzymes were inactivated by heating at $80^{\circ} \mathrm{C}$ for 15 min, and an aliquot of the treated PCR products (5 to $10 \mathrm{ng}$ of DNA per $100 \mathrm{bp}$ of product) was used directly in sequencing reactions. Sequencing primers were the same as those used in the initial PCR reactions.

PCR products were sequenced using Taq cycle sequencing with fluorescence-based chain termination chemistry (Perkin-Elmer/Applied Biosystems) and automatic DNA sequencers (Perkin-Elmer/Applied Biosystems, models 373A or 377). Sequences of both DNA strands were determined. DNA sequence traces (electropherograms) were edited, and DNA contigs were assembled with the aid of a computer program (Sequencer, v 3.0; Gene Codes Corp., Ann Arbor, MI).

Table 1. Primers designed for detecting cowpea mottle virus

\begin{tabular}{llc}
\hline Primer designation & Primer sequence $\left(\mathbf{5}^{\prime} \mathbf{-} \mathbf{3}^{\prime}\right.$, base pairs $)$ & Predicted PCR product size \\
\hline $\begin{array}{l}\text { Nondegenerate } \\
\text { REP forward-1667F }\end{array}$ & AAC AAC GGA GAT GAC TGT GT & \\
REP reverse-1990R & TAC GCT TGC TGT ATG GGT AT & $1667 \mathrm{~F} / 1990 \mathrm{R}=323 \mathrm{bp}$ \\
MOV $^{\mathrm{b}}$ reverse-2666R & TTG AAG AGA GGG AGG AGA AG & $1667 \mathrm{~F} / 2666 \mathrm{R}=999 \mathrm{bp}$ \\
\hline
\end{tabular}

\footnotetext{
a RNA replicase coding region.
}

${ }^{\mathrm{b}}$ Movement protein coding region.
Primer sensitivity and specificity. Two approaches were used to test the sensitivity of the primers. First, RT-PCRs were performed using 10 -fold dilutions $\left(10^{0}\right.$ to $\left.10^{-9}\right)$ of the purified viral RNA as template. Second, leaf disks were removed from healthy and diseased leaves and diluted as follows: $1 / 10$ (one virus-infected leaf disk: nine healthy disks), 1/50,1/100,1/500, and $1 / 1,000$. The disks were removed with a cork borer of a size such that the total weight of leaf disks was about $0.5 \mathrm{~g}$. The disks were then extracted as described above, and the total RNA was used as template for RT-PCR.

Specificity of the primers was tested against BBMV-RNA and MNSV-RNA from purified virus. In addition, tissue samples of alfalfa mosaic virus, blackeye cowpea mosaic potyvirus, cowpea chlorotic mottle bromovirus, cowpea severe mosaic comovirus, cucumber mosaic cucumovirus, peanut stunt cucumovirus, southern bean mosaic sobemovirus, sunn hemp mosaic tobamovirus, and white clover mosaic potexvirus were extracted and tested to determine if any common cowpea pathogens would react with the primers.

Comparison of RT-PCR and DACELISA. Several approaches were used to compare ELISA and RT-PCR. The first approach utilized leaf disks as described above for testing sensitivity in RT-PCR. Each leaf disk dilution (1/10 to $1 / 1,000)$ was ground in an extraction buffer, $\mathrm{pH} 7.1$, used for DAC-ELISA (5), and the serology test was conducted on these samples using the polyclonal CPMoV antiserum. These data were then compared with those obtained by RT-PCR on the leaf disk dilution. The second approach involved diluting purified CPMoV (starting concentration of about $5 \mathrm{mg} / \mathrm{ml}$ based on $A_{260}$ ) and also crude leaf extracts in the DAC-ELISA extraction buffer mentioned above. A portion of each dilution was used in an ELISA (200 $\mu \mathrm{l}$ in each of two wells in the microtiter plate). A 400- $\mu$ l sample of each was extracted by the phenol:chloroform method described above and used in RT-PCR.

\section{RESULTS}

Sensitivity and specificity of primers. Both pairs of primers from the REP region (Table 1) were found to be highly sensitive and produced a single product upon amplification. The CP primers also produced a single amplification product and had a low sensitivity compared with the REP primers. All of the degenerate primer pairs tested gave inconsistent results and sometimes produced erroneous bands of the incorrect size (data not shown). The primers from the REP region were judged to be most reliable and were used almost exclusively in the remaining tests.

The RT-PCR results for the replicase primer pairs assayed against extracts from both CPMoV-infected and healthy tissues indicated a single product of the expected 
size for each pair with the infected tissue (Fig. 1). DNA sequences obtained for the 323-bp fragment amplified by REP1667F/ REP1990R matched the expected CPMoV sequences published for the ISU product. The 323-bp fragment amplified by REP1667F/REP1990R for CPMoV-AT matched the published sequence with 13 base substitutions (Fig. 2). Primers REP1667F/REP1990R detected CPMoV-ISU in one infected plant mixed with 99 healthy plants, and REP1667F/MOV$2666 \mathrm{R}$ produced a product at a dilution of one infected plant per 49 healthy plants, but no bands were visible at further dilutions of infected with healthy plants (Fig. 3A). Results using serial dilutions of purified viral RNA were similar. Primer pair REP1667F/REP1990R produced a specific PCR product at a $10^{-6}$ dilution $\left(\sim 2.6 \times 10^{-1} \mathrm{pg} / \mu \mathrm{l}\right)$ of CPMoV-AT-RNA, but primer pair $1667 \mathrm{~F} / 2666 \mathrm{R}$ produced a faint band at $10^{-5}$ dilution of the RNA (Fig. 3B). The lesser sensitivity for the $1667 \mathrm{~F} / 2666 \mathrm{R}$ primer pair is probably an artifact of PCR in which the longer fragment cannot be replicated as efficiently as the shorter one.

The comparisons of DAC-ELISA and RT-PCR for detection of CPMoV indicated that PCR is much more sensitive (Table 2). ELISA detected virus in one infected plant in 75 , compared with the REP1667F/ REP1990R primer pair, which detected virus in one plant in 1,000, as discussed in the previous paragraph. The ELISA results with the diluted purified virus indicated an end point at $10^{-7}$ dilution, and the PCR (Fig. 3C) detected virus at $10^{-12}$ dilution or $\sim 5 \times 10^{-3} \mathrm{pg} / \mathrm{ml}$ (no end point was obtained in the PCR). ELISA of the crude tissue extract dilution series yielded a $10^{-6}$ end point, but the PCR (Fig. 3D) detected virus at $10^{-9}$ dilution (no end point obtained).

\section{6}

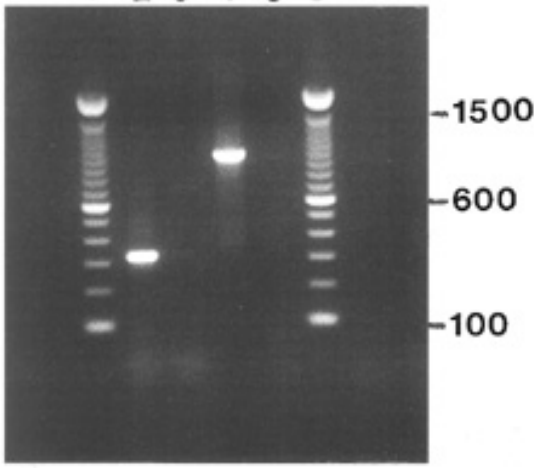

Fig. 1. Reverse transcription-polymerase chain reaction (RT-PCR) bands in agarose gel with cowpea mottle virus-ISU. Lanes 2 and $3=$ RNA from virus-infected and healthy cowpea, respectively, with primer pair REP1667F/ REP1990R; lanes 4 and $5=$ RNA from infected and healthy cowpea, respectively, with REP1667F/ MOV2666R. Lanes 1 and $6=$ markers (100-bp ladder).
Togo AACAACGGAG ATGACTGTGT GGTTATTACC GAGTCCAAGA ACGTTGATTT

ISU AACAACGGAG ATGACTGTGT GGTTATTACC GAGTCCAAGA ACGTTGATTT

51

100

AT CGTATGCAAG CAGTTGgAAC GATTCCGCGA TTACGgGtTT ACGTGCATAG

Togo CGTATGCAAG CAGTTGgAAC GATTCCGCGA TTACGgGTTt ACGTGCATAG

ISU CGTATGCAAG CAATTGGAAC GATTCCGCGA CTATGGGTTT ACGTGCATAG

101

150

AT

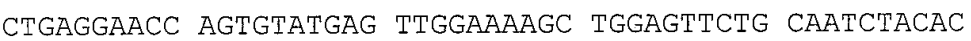

Togo ctgaggaAcc agtgtatgag tiggaAaAg tggagttctg cAatctacac

ISU CTGAgGAACC Agtgtatgag tTgGAAAAgC TGgAgtTCtg taAtctacAC

151

200

AT

CCACTGTTTG ATGGCTCCTC CTGGACGgTg ATGCGgAAAC CAAGTGTTTC

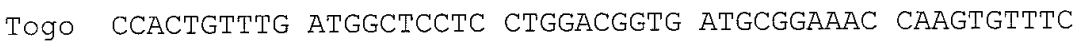

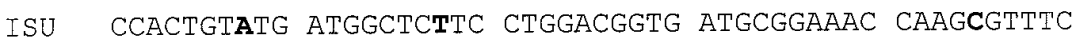

201

AT ATTAGCCAAG GACACCTATT GTGTGGCTGG ATGGAACAAC ACCAAGGATG

Togo ATTAGCCAAG GACACCTATT GTGTGGCTGG ATGGAACAAC ACCAAGGATG

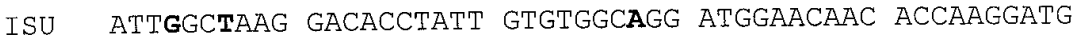

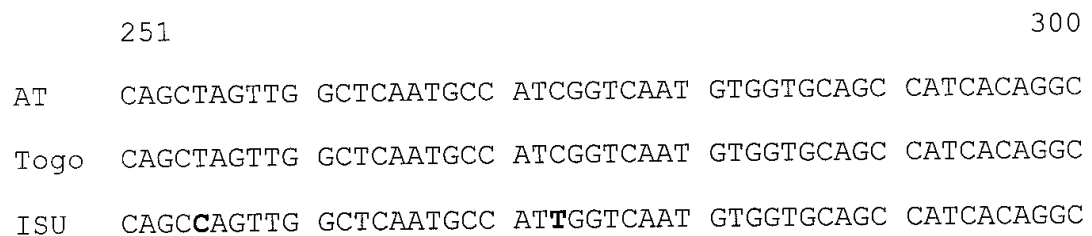

ISU

CAGCCAGTTG GCTCAATGCC ATTGGTCAAT GTGGTGCAGC CATCACAGGC

$\begin{array}{lll} & 301 & 323 \\ \text { AT } & \text { GGTATACCCA } & \text { TACAGCAAGC } \\ \text { TOgA } \\ \text { ISU } & \text { GGTATACCCA TACAGCAAGC GTA }\end{array}$

Fig. 2. DNA sequence alignment for 323 bases from the replicase gene of three cowpea mottle virus isolates. Variant nucleotides are in bold type, and primer sequences (REP1667F and REP 1990R) are underlined. 
Specificity of the primers was tested against other carmoviruses, BMMV-RNA and MNSV-RNA from purified virus, as well as against tissue extracts of cowpeas infected with other common cowpea pathogens. BMMV-RNA, MNSV-RNA, and the other cowpea viral-pathogen extracts produced no 323-bp fragment in PCR with REP1667F/REP1990R or a 999-bp fragment with REP1667F/MOV2666R. Interestingly, the degenerate primer pairs mentioned earlier were generally observed to amplify fragments of the same size using CPMoV, BMMV, and MNSV templates, indicating an unacceptable level of cross-reactivity in this assay (data not shown).

Specificity of primers. To determine the range of reaction of the primers to different $\mathrm{CPMoV}$ isolates, 29 samples representing 11 separate isolates were increased on cowpea PI 471475 in growth chambers, and total RNA was extracted from each. RT-PCR was performed using the REP1667F/REP1990R primer pair, and all 29 extracts produced the expected band (data not shown). Sequencing was performed on PCR products obtained from ISU, AT, and several Togo isolates. DNA sequences from the 323-bp fragment amplified by primer pair REP1667F/
REP1990R were identical for all isolates from Togo. Furthermore, the Togo sequences were almost identical to those derived from the AT isolate (there was a single base difference at position 321, Fig. 2). The AT sequence was more divergent, with 13 base substitutions, compared with ISU.
Primers for seedborne virus detection. The results obtained from tests of seedlings from a total of 1,000 seeds from eight different infected cowpea genotypes indicated $\mathrm{CPMoV}$ was not transmitted, as determined by both RT-PCR and ELISA. Samples were bulked to five plants per sample for serology and to 50 plants per sample

Table 2. Comparison of enzyme-linked immunosorbent assay (ELISA) and reverse transcriptionpolymerase chain reaction (RT-PCR) sensitivity for crude extract and pure virus of cowpea mottle carmovirus-ISU

\begin{tabular}{|c|c|c|c|c|}
\hline \multirow[b]{2}{*}{ Dilution $^{a}$} & \multicolumn{2}{|c|}{ Crude extract } & \multicolumn{2}{|c|}{ Pure virus } \\
\hline & $\operatorname{ELISA}\left(A_{405}\right)$ & RT-PCR $^{\text {b }}$ & $\operatorname{ELISA}\left(A_{405}\right)$ & RT-PCR $^{b}$ \\
\hline $10^{-3}$ & 0.937 & + & nt & nt \\
\hline $10^{-4}$ & 0.938 & + & 0.943 & + \\
\hline $10^{-5}$ & 0.928 & + & 0.937 & + \\
\hline $10^{-6}$ & 0.738 & + & 0.917 & + \\
\hline $10^{-7}$ & 0.036 & + & 0.224 & + \\
\hline $10^{-8}$ & - & + & - & + \\
\hline $10^{-9}$ & - & + & - & + \\
\hline $10^{-10}$ & nt & $\mathrm{nt}$ & - & + \\
\hline $10^{-11}$ & nt & $\mathrm{nt}$ & - & + \\
\hline $10^{-12}$ & nt & nt & - & + \\
\hline
\end{tabular}

a Samples for direct antigen coating-ELISA diluted in $0.15 \mathrm{M} \mathrm{NaCl}, 0.036 \mathrm{M} \mathrm{Na}_{2} \mathrm{HPO}_{4}, 0.016 \mathrm{M}$ $\mathrm{NaH}_{2} \mathrm{PO}_{4}, 0.013 \mathrm{M} \mathrm{Na}$ DIECA, $0.003 \mathrm{M} \mathrm{NaN}_{3}, \mathrm{pH} 7.1$.

${ }^{\mathrm{b}}$ Samples for RT-PCR were extracted from the various dilutions for ELISA by incubation at $37^{\circ} \mathrm{C}$ for $1 \mathrm{~h}$ in sodium dodecyl sulfate (SDS) and EDTA followed by treatment with chloroform/phenol (1:1 vol/vol) and precipitation in ethanol. Primer set REP1667F/REP1990R was used, and results can be seen in Figure 3C and D.
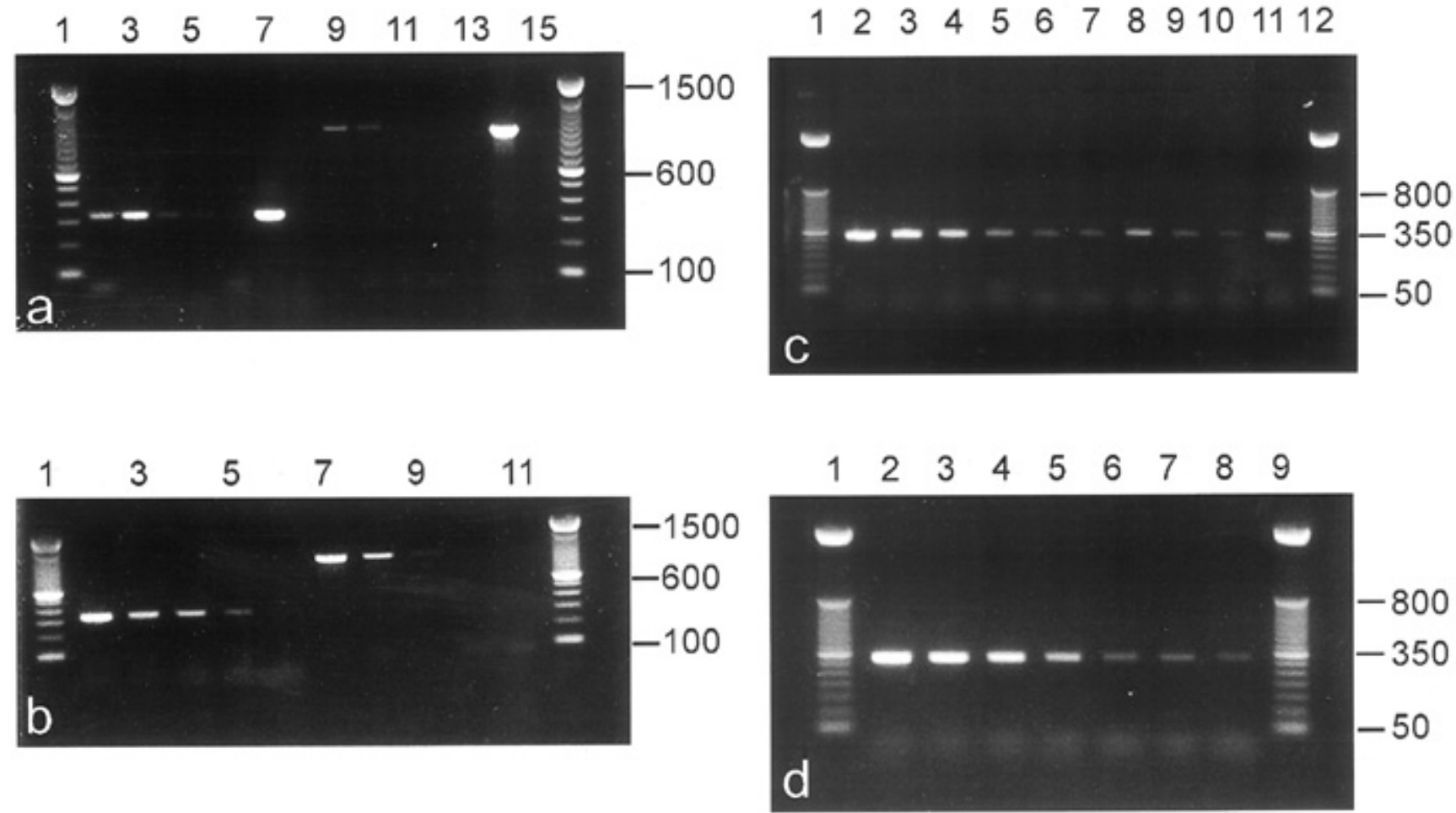

Fig. 3. (A) Reverse transcription-polymerase chain reaction (RT-PCR) bands in agarose gel with tissue dilutions of cowpea mottle virus (CPMoV)-ISUinfected cowpea. Lanes 2 to $8=1$ infected plant/10 plants, $1 / 50,1 / 100,1 / 500,1 / 1,000$, RNA from purified virus, and healthy cowpea, respectively, with primer pair REP1667F/REP1990R; lanes 9 to $15=1$ infected plant/10 plants, 1/50, 1/100, 1/500, 1/1000, RNA from purified virus, and healthy cowpea, respectively, with REP1667F/MOV2666R. Lanes 1 and $16=$ markers (100-bp ladder). (B) RT-PCR bands in agarose gel with dilutions of CPMoV RNA. Lanes 2 to $6=10^{-3}, 10^{-4}, 10^{-5}, 10^{-6}, 10^{-7}$ CPMoV-AT RNA, respectively, with primer pair REP1667F/REP1990R; lanes 7 to $11=10^{-3}, 10^{-4}, 10^{-5}, 10^{-6}$, $10^{-7}$ CPMoV-AT RNA, respectively, with REP1667F/MOV2666R. Lanes 1 and 12 = markers (100-bp ladder). (C) RT-PCR with a dilution series of purified CPMoV-ISU (starting virus concentration of $\sim 5 \mathrm{mg} / \mathrm{ml}$ ). Lanes 2 to $10=10^{-4}, 10^{-5}, 10^{-6}, 10^{-7}, 10^{-8}, 10^{-9}, 10^{-10}, 10^{-11}$, 10 $0^{-12}$ dilutions, respectively, tested with REP1667F/REP1990R. Lane $11=$ RNA $(\sim 250 \mathrm{ng} / \mu \mathrm{l})$ from purified CPMoV. Lanes 1 and 12 = markers (50-bp ladder). (D) RT-PCR of CPMoV -ISU-infected tissue. Lanes 2 to $8=10^{-3}, 10^{-4}, 10^{-5}, 10^{-6}, 10^{-7}, 10^{-8}, 10^{-9}$ dilutions, respectively, tested with REP1667F/REP1990R. Lanes 1 and $9=$ markers (50-bp ladder). 
for RT-PCR. There were 10 instances where ELISA gave marginal results (false positives) with some samples. When these plants were then tested by RT-PCR, they were found to be negative for $\mathrm{CPMoV}$. Further attempts to achieve seed transmission with $\mathrm{CPMoV}$ inoculated into California Blackeye no. 5 from 2 to 4 weeks after the primary leaf stage also failed to yield any virus in the 120 seeds tested.

\section{DISCUSSION}

This RT-PCR procedure, based on the sensitivity and specificity of at least one set of primers, is the most sensitive method developed to date to detect CPMoV. The fact that seed transmission did not occur in our tests does not eliminate seedborne $\mathrm{CPMoV}$ from consideration as a problem in germ plasm exchange, but rather indicates that seed transmission occurs at low rates as reported by others $(1,4,12)$. In a laboratory/greenhouse study of seed transmission of CPMoV (10), plants inoculated at the primary leaf stage produced $1 \%$ infected seeds; whereas plants inoculated when the second trifoliolate leaves were expanding, produced $6 \%$ infected seeds. This tendency for greater seed transmission when plants are infected later in the season could explain some of the differences in seed transmission rates that have been observed. This virus is a very serious threat in the movement of genetic resources of Vigna because of its potential for severe damage to crops. In the tests comparing RT-PCR and ELISA (Fig. 3C and D), twice the volume was extracted for RT-PCR as was used for each well in the ELISA, so these end comparative dilutions may be misleading. A similar problem exists with the tissue dilution test comparisons mentioned previous to these tests. However, this twofold volume difference is insig- nificant when compared to the PCR assay, which is three to five orders of magnitude more sensitive.

Nondegenerate primers designed from the replicase gene are clearly a better choice for sensitive, accurate detection of $\mathrm{CPMoV}$ than the degenerate primers used in these tests. The use of these primers in RT-PCR offers a definite increase in sensitivity over the ELISA detection methods and will solve many problems arising with marginal ELISA results (false positives). False positive results occurred with cowpea plants of several different genotypes, but not all plants arising from a particular seed lot showed this response. Furthermore, dilutions of $1 / 100$ did not eliminate the response in earlier studies, nor did it work here (5). Many seed lots in the collection are not genetically homogeneous. Apparently there are proteins among plants of certain seed lots that give a nonspecific serological reaction.

\section{ACKNOWLEDGMENTS}

We thank M. Y. D. Gumedzoe, University of Benin, Lome, Togo, and G. Thottappilly, International Institute for Tropical Agriculture, Ibadan, Nigeria, for supplying isolates of CPMoV; V. Hari, Wayne State University, Detroit, for BMMV; and D. M. Rochon, Agriculture and Agrifood Canada, Summerland, BC, Canada, for MNSV. Mention of a trademark or a proprietary product does not constitute a guarantee or warranty of the product by the U.S. Department of Agriculture and does not imply its approval to the exclusion of other products that may also be available.

\section{LITERATURE CITED}

1. Allen, D. J., Thottappilly, G., and Rossel, H. W. 1982. Cowpea mottle virus: Field resistance and seed transmission in virus-tolerant cowpea. Ann. Appl. Biol. 100:331-336.

2. Altschul, S. F., Gish, W., Miller, W., Myers, E. W., and Lipman, D. J. 1990. Basic local alignment search tool. J. Mol. Biol. 215:403410 .

3. Benson, D. A., Boguski, M., Lipman, D. J., and Ostell, J. 1996. GenBank. Nucleic Acids Res. 24:1-5.

4. Bozarth, R. F., and Shoyinka, S. A. 1979. Cowpea mottle virus. CMI/AAB Descriptions of Plant Viruses, No. 212. Commonw. Mycol. Inst./Assoc. Appl Biol., Kew, Eng.

5. Gillaspie, A. G., Jr., Hopkins, M. S., Pinnow, D. L., and Hampton, R. O. 1995. Seedborne viruses in preintroduction cowpea seed lots and establishment of virus-free accessions. Plant Dis.79:388-391.

6. Kim, J. W., and Bozarth, R. F. 1992. Mapping and sequence analysis of the capsid protein gene of cowpea mottle virus. Intervirology 33:135-147.

7. MacKenzie, D. J., McLean, M. A., Mukerji, S., and Green, M. 1997. Improved RNA extraction from woody plants for the detection of viral pathogens by reverse transcriptionpolymerase chain reaction. Plant Dis. 81:222 226.

8. Morozov, S. Y., Ryabov, E. V., Leiser, R. M., and Zavriev, S. K. 1995. Use of highly conserved motifs in plant virus RNA polymerases as the tags for specific detection of carmovirus-related RNA-dependent RNA polymerase genes. Virology 207:312-315.

9. Robertson, D. G. 1963. Cowpea virus research in Nigeria. Proc. Nigerian Grain Legume Conf., 1st., Samaru, Zaria, Inst. Agric. Res., Ahmadu Bello Univ.

10. Shoyinka, S. A., Bozarth, R. F., Reese, J., and Rossel, H. W. 1978. Cowpea mottle virus: A seed-borne virus with distinctive properties infecting cowpeas in Nigeria. Phytopathology 68:693-699.

11. Shoyinka, S. A., Thottappilly, G., Adebayo, G. G., and Anno-Nyako, F. O. 1997. Survey on cowpea virus incidence and distribution in Nigeria. Intl. J. Pest Manage. 43:127-132.

12. Thottappilly, G., and Rossel, H. W. 1992. Virus diseases of cowpea in tropical Africa. Trop. Pest Manage. 38:337-348.

13. Waterworth, H. 1981. Bean mild mosaic virus. CMI/AAB Descriptions Plant Viruses. No. 231. Commonw. Mycol. Inst./Assoc. Appl. Biol., Kew, Eng.

14. You, X. J., Kim, J. W., Stuart, G. W., and Bozarth, R. F. 1995. The nucleotide sequence of cowpea mottle virus and its assignment to the genus Carmovirus. J. Gen. Virol. 76:28412845 . 